\title{
Impact of preoperative weight loss and body composition changes on postoperative outcome in surgery for inflammatory bowel disease
}

\author{
C S HIGGENS, M R B KEIGHLEY, AND R N ALLAN \\ From the Gastroenterology Unit, The General Hospital, Birmingham
}

SUMMARY One hundred and twenty seven patients undergoing elective surgery for inflammatory bowel disease were divided into three groups according to their preoperative ideal body weight $(<80 \%, 80-90 \%$, and $>90 \%)$. The groups were well matched in respect of age, sex, corticosteroid therapy, pre-existing sepsis, peroperative antimicrobial chemotherapy, and resection site. None received peroperative nutritional support. The postoperative outcome was similar in each of the three nutritional groups including the incidence of postoperative sepsis, duration of hospital stay, and mortality. Serial peroperative changes in weight, fat, and muscle bulk were assessed by anthropometric measurements in 21 of these patients. The deficits in weight, fat, and muscle bulk were similar at 10 and 21 days postoperatively in the three groups. At 84 days those malnourished preoperatively had recovered their nutritional status faster than the well nourished patients. We conclude that in these patients undergoing elective resection for inflammatory bowel disease preoperative weight loss did not adversely affect the postoperative outcome.

It is uncertain whether preoperative weight loss, which is common in surgical patients ${ }^{1}$ and particularly so in patients with inflammatory bowel disease, ${ }^{2}$ adversely affects the postoperative outcome. Evidence for an adverse effect includes epidemiological data derived mainly from children in the developing countries where malnutrition is associated with an increased risk of sepsis. ${ }^{3-5}$ Laboratory studies in protein depleted animals suggest that they are susceptible to bacterial infections $^{6}$ and also have impaired strength of surgical anastomoses. ${ }^{7}$ The controversy has been examined in man by a number of workers who have provided preoperative nutritional support and assessed the postoperative outcome. Preoperative nutritional support improved the postoperative outcome in some studies, ${ }^{89}$ but not in others. ${ }^{10} 11$ We have approached the problem differently in this study by examining the postoperative morbidity in a consecutive series of patients with inflammatory bowel disease undergoing elective surgery for resection grouped according to their preoperative ideal body weight. The peroperative changes in

Address for correspondence: Dr R N Allan, Gastroenterology Unit, The General Hospital, Steelhouse Lane, Birmingham B4 6NH.

Received for publication 19 September 1983 weight, fat, and muscle bulk have been assessed by detailed anthropometric measurement ${ }^{12-16}$ in 21 of these patients.

\section{Methods}

PATIENTS

One hundred and twenty seven consecutive patients undergoing elective surgical resection for inflammatory bowel disease (Crohn's disease $n=112$, ulcerative colitis $n=15$ ) between 1974 and 1980 whose wounds were closed by primary suture were studied. They were allocated to one of three nutritional groups according to their preoperative ideal body weight, corrected for height, sex, and age $^{14}(<80 \%, 80-90 \%$, and $>90 \%$ of ideal body weight) and a proforma was completed for each patient which included details of age, sex, site of disease, nature of the surgical resection, corticosteroid therapy, pre-existing sepsis, and peroperative antimicrobial chemotherapy. The postoperative outcome was monitored for evidence of wound sepsis, abscess, and septicaemia. Minor sepsis was defined as localised pus in the incision with little systemic disturbance. Major sepsis was defined as a wound or abdominal abscess 
discharging pus either spontaneously or after surgical drainage with severe constitutional symptoms and clinical bacteraemia.

The peroperative changes in weight, fat, and protein were determined by serial anthropometric studies in 21 of these patients whose protein status preoperatively was measured by expressing arm muscle circumference as a percentage of their standard arm muscle circumference for age and sex. The proportion of body weight as fat ( $\%$ fat) was derived from the mean of three measurements of mid-non-dominant triceps skinfold thickness. ${ }^{15}$ Muscle bulk was estimated by measuring arm muscle circumference. ${ }^{16}$ The postoperative changes in weight, muscle mass, and percentage fat were expressed as a percent change from their preoperative value in each patient.

The mean percentage change in muscle mass, fat, and weight were derived for the patients in each of the three nutritional groups at 10,21 , and 84 days postoperatively. Anthropometric measurements were all carried out by one observer (CSH). The mean difference between duplicate measurements of skinfold thickness were $3.2 \%$ and for duplicate measurements of arm muscle circumference $1.3 \%$.

\section{STATISTICAL ANALYSIS}

Statistical analysis was by Student's $t$ tests and regression analysis.

\section{Results}

OVERALL

The three nutritional groups were well matched in respect of the preoperative variables which might affect the postoperative outcome including age, sex, nature of surgical resection, and the incidence of pre-existing sepsis and peroperative corticosteroid therapy. Well nourished patients had a marginally higher incidence of peroperative antimicrobial chemotherapy (Table 1).

The incidence and sites of postoperative sepsis was similar in the three groups (Table 2). There were no postoperative deaths. The incidence of postoperative sepsis was similar to that recorded in previous studies. ${ }^{16}$ There was no significant difference in the duration of hospital stay in the three nutritional groups.

\section{SMALL BOWEL RESECTIONS}

The 89 patients undergoing small bowel resection ( \pm the adjacent colon) were also well matched in respect of preoperative variables which might affect the postoperative outcome. The postoperative sepsis rates were similar in each group and were not increased in the severely malnourished patients (Table 3).

\section{ANTHROPOMETRIC DATA}

The clinical details of the 21 patients with Crohn's disease whose nutritional status was assessed serially is shown in Table 4 . These patients were allocated into nutritional groups according to their preoperative body weight expressed as a percentage ideal body weight. The protein status for each group was also defined by measuring each individual's arm muscle circumference and expressing it as a percentage standard for age and sex. The mean percentage standards for each nutritional group was measured and showed that those malnourished as defined by $\%$ ideal body weight were also protein malnourished (Table 4).

The average age of the malnourished group ( $<80 \%$ ideal body weight) was higher than the other groups but they were well matched in all other respects.

Postoperative sepsis was uncommon and there were two episodes of major sepsis. The mean overall

Table 1 Preoperative variables: all patients grouped according to ideal body weight (IBW)

\begin{tabular}{|c|c|c|c|c|}
\hline & \multicolumn{3}{|c|}{ \% Ideal body weight } & \multirow[b]{2}{*}{ All } \\
\hline & $<80$ & $80-90$ & $>90$ & \\
\hline Crohn's disease & 37 & 30 & 45 & 112 \\
\hline Ulcerative colitis & 1 & 8 & 6 & 15 \\
\hline Mean \% IBW & $70 \cdot 9 \pm 6 \cdot 0$ & $84 \cdot 6 \pm 3 \cdot 3$ & $104 \cdot 8 \pm 13 \cdot 8$ & $88 \cdot 6 \pm 17 \cdot 2$ \\
\hline Men & 14 & 16 & 20 & 50 \\
\hline Women & 24 & 22 & 31 & 77 \\
\hline Mean age $(y r)$ & $32 \cdot 4$ & $37 \cdot 5$ & $40 \cdot 0$ & 37 \\
\hline Pre-existing sepsis & 8 & 10 & 12 & $30(24 \%)$ \\
\hline Peroperative corticosteroid therapy & 24 & 22 & 27 & $73(57 \%)$ \\
\hline Peroperative antimicrobial therapy & 21 & 16 & 31 & $68(53 \%)$ \\
\hline Resection of small bowel and colon & 27 & 25 & 37 & 89 \\
\hline Colectomy + ileorectal anastomosis & 8 & 4 & 4 & 16 \\
\hline Panproctocolectomy & 3 & 9 & 10 & 22 \\
\hline
\end{tabular}


Table 2 Sepsis after surgical resection: all patients

\begin{tabular}{|c|c|c|c|c|c|}
\hline \multirow{2}{*}{$\begin{array}{l}\% \text { Ideal } \\
\text { body } \\
\text { weight }\end{array}$} & \multirow{2}{*}{$\begin{array}{l}\text { Patients } \\
\text { (no) }\end{array}$} & \multicolumn{3}{|l|}{ Sepsis } & \multirow{2}{*}{$\begin{array}{l}\text { Duration } \\
\text { of } \\
\text { hospital } \\
\text { stay } \\
\text { (days) }\end{array}$} \\
\hline & & Minor & Major & None & \\
\hline$<80$ & 38 & $4(10.5 \%)$ & $6(16 \%)$ & $28(74 \%)$ & $21 \cdot 1 \pm 13 \cdot 4$ \\
\hline $80-90$ & 38 & $3(8 \%)$ & $5(13 \%)$ & $30(79 \%)$ & $20 \cdot 3 \pm 13 \cdot 2$ \\
\hline$>90$ & 51 & $6(12 \%)$ & $7(14 \%)$ & $38(74 \%)$ & $16 \cdot 6 \pm 7 \cdot 4$ \\
\hline Total & 127 & $13(10 \%)$ & $18(14 \%)$ & $96(76 \%)$ & $19 \cdot 1 \pm 11 \cdot 3$ \\
\hline
\end{tabular}

There was no significant difference between duration of hospital stay in the three groups.

duration of hospital stay in each group is shown in Table 4 . The malnourished patients $(<80 \%$ ideal body weight) without complications had a mean postoperative stay of $14 \cdot 8 \pm 4 \cdot 6$ days compared with $10 \cdot 7 \pm 3.4$ days in the well nourished group, but the differences were not statistically significant.

The mean duration of hospital stay was $28 \pm 10 \cdot 1$ days (range 14-38 days) in those patients with postoperative complications which was significantly longer than those without complications $(p=0 \cdot 01$; Student's $t$ test). There was no correlation between nutritional status ( $\%$ ideal body weight) and duration of hospital stay $(r=-0 \cdot 29, t=1 \cdot 13$, NS).

The analysis of the postoperative changes in weight and its components (\% fat and muscle mass) with the patients grouped according to their preoperative ideal body weight is shown in the Figure a,b,c. Weight loss was similar in the three groups at 10 and 21 days (Fig. a). At 84 days the severely malnourished gained more weight $(+8.5 \%)$ when compared with the well nourished $(-1 \cdot 1 \%)$.

The changes in percentage body fat ( $\%$ fat) were similar to the weight changes in the postoperative period (Fig. b). At 84 days, however, the poorly nourished patients ( $<80 \%$ ideal body weight) had a mean gain of $33.9 \%$ from their preoperative fat status compared with the intermediate group (80-

Table 3 Sepsis after small bowel resection alone

\begin{tabular}{|c|c|c|c|c|}
\hline \multirow{2}{*}{$\begin{array}{l}\text { \% Ideal } \\
\text { body } \\
\text { weight }\end{array}$} & \multirow{2}{*}{$\begin{array}{l}\text { Patients } \\
\text { (no) }\end{array}$} & \multicolumn{3}{|l|}{ Sepsis } \\
\hline & & Minor & Major & None \\
\hline$<80$ & 27 & $3(11 \%)$ & $\begin{array}{l}3 \text { Pelvic abscess } \\
\text { Wound abscess (2) }\end{array}$ & $21(78 \%)$ \\
\hline $80-90$ & 25 & $2(8 \%)$ & $\begin{array}{l}3 \text { Abdominal abscess } \\
\text { Pelvic abscess } \\
\text { Perirectal abscess }\end{array}$ & $20(80 \%)$ \\
\hline$>90$ & 37 & $3(8 \%)$ & $\begin{array}{l}4 \text { Wound abscess (3) } \\
\text { Abdominal sepsis }\end{array}$ & $30(81 \%)$ \\
\hline Total & 89 & $8(9 \%)$ & 10 & $71(80 \%)$ \\
\hline
\end{tabular}

$90 \%$ ideal body weight) who had gained $15.9 \%$. The well nourished ( $>90 \%$ ideal body weight) had a mean loss of $4.4 \%$ from their preoperative status.

The mean changes in muscle mass as measured by arm muscle circumference were small (Fig. c), and similar to the weight changes observed in each group. The severely malnourished patients, however, were slow to reverse their negative deficit of $-8 \%$ at 10 days and $-6 \%$ at 21 days. Those who were malnourished ( $<80 \%$ ideal body weight) showed the greatest mean percentage gain in muscle mass $(+12 \%)$ at 84 days.

\section{Discussion}

This study confirms the conclusions of a preliminary study ${ }^{17}$ that the extent of preoperative weight loss observed in these patients did not adversely affect the postoperative outcome. In particular we found that preoperative weight loss did not influence the incidence of postoperative sepsis.

The three nutritional groups were well matched in respect of variables which might affect the postoperative outcome by modifying the immune response, ${ }^{18}$ though in practice corticosteroid therapy (possibly because of the use of appropriate peroperative antimicrobial chemotherapy) does not seem to adversely affect postoperative sepsis rates. ${ }^{17-20}$

The data from children in developing countries where malnutrition is associated with severe sepsis ${ }^{5}$ while emphasising the hazards of malnutrition cannot be extrapolated to predict the outcome in previously well nourished adult patients who present with weight loss at the time of surgical treatment for inflammatory bowel disease.

Anthropometric measurements are important in the assessment of protein calorie malnutrition and the measurement of components of weight change in surgical patients. ${ }^{13-21}$ They are particularly useful in patients with inflammatory bowel disease, where measurement of serum proteins are unreliable for assessing malnutrition as the disease is often associated with protein loss into the bowel lumen.

The patients undergoing anthropometric measurements were divided into three nutritional groups determined by ideal body weight as previously defined. ${ }^{22}$ These groups corresponded well with protein status as defined by percentage standard arm muscle circumference. The deficits in weight and muscle bulk were similar in all three groups at 10 and 28 days postoperatively and illustrate the metabolic response commonly observed after surgical intervention.

The changes in the individual components by anthropometric measurement were of the same 
Table 4 Clinical data of the 21 Crohn's patients having serial anthropometric measurements

\begin{tabular}{lllll}
\hline \% Ideal body weight & $<80$ & $80-90$ & $>90$ & Total \\
\hline Preoperative data & & & & \\
$\quad$ Mean \% IBW & $72 \cdot 1 \pm 4 \cdot 7$ & $84 \cdot 7 \pm 3 \cdot 7$ & $107 \cdot 7 \pm 11 \cdot 9$ & $89 \cdot 2 \pm 17$ \\
Patients (no) & 7 & 6 & 8 & 21 \\
Mean age (range)(yr) & $51(19-73)$ & $37 \cdot 5(24-58)$ & $36 \cdot 3(11-58)$ & $41 \cdot 5(11-73)$ \\
Mean AMC (cm) & $18 \cdot 3 \pm 1 \cdot 98$ & $21 \cdot 9 \pm 3 \cdot 7$ & $22 \cdot 4 \pm 1 \cdot 6$ & $20 \cdot 6 \pm 3 \cdot 1$ \\
Mean \% standards AMC (range) & $76 \cdot 1 \pm 6 \cdot 9(68-87)$ & $87 \cdot 1 \pm 4 \cdot 1(82-93)$ & $98 \cdot 0 \pm 5 \cdot 1(93-105)$ & $87 \cdot 6 \pm 10 \cdot 8(68-105)$ \\
Preoperative sepsis & 2 & 0 & 1 & 3 \\
$\quad$ Peroperative corticosteroid therapy & 4 & 2 & 4 & 10 \\
$\quad$ Peroperative antimicrobial therapy & 7 & 4 & 6 & 17 \\
Postoperative data & 1 & 0 & 1 & 2 \\
$\quad$ Major sepsis & 0 & 1 & 0 & 1 \\
$\quad$ Minor sepsis & 1 (bleeding DU) & 1 (pulmonary embolus) & 0 & 2 \\
$\quad$ Other complications & $14 \cdot 8 \pm 4 \cdot 6$ & $13 \cdot 8 \pm 5 \cdot 2$ & $10 \cdot 7 \pm 3 \cdot 4$ & $104 \pm 14$ \\
Those without complications & $77 \cdot 6 \pm 6 \cdot 7$ & $89 \cdot 1 \pm 6 \cdot 1$ & & $92 \cdot 8 \pm 4 \cdot 4$ \\
$\quad$ Duration of hospital stay (days) & & & & \\
Mean \% IBW at 84 days & & & \\
\hline
\end{tabular}

Figure a,b,c Postoperative outcome in patients grouped according to their preoperative percentage ideal body weight (\% IBW). All changes are expressed as mean percentage change from preoperative value. (a) Weight changes after surgery; (b) changes in \% body fat after surgery; (c) changes in muscle bulk after surgery.

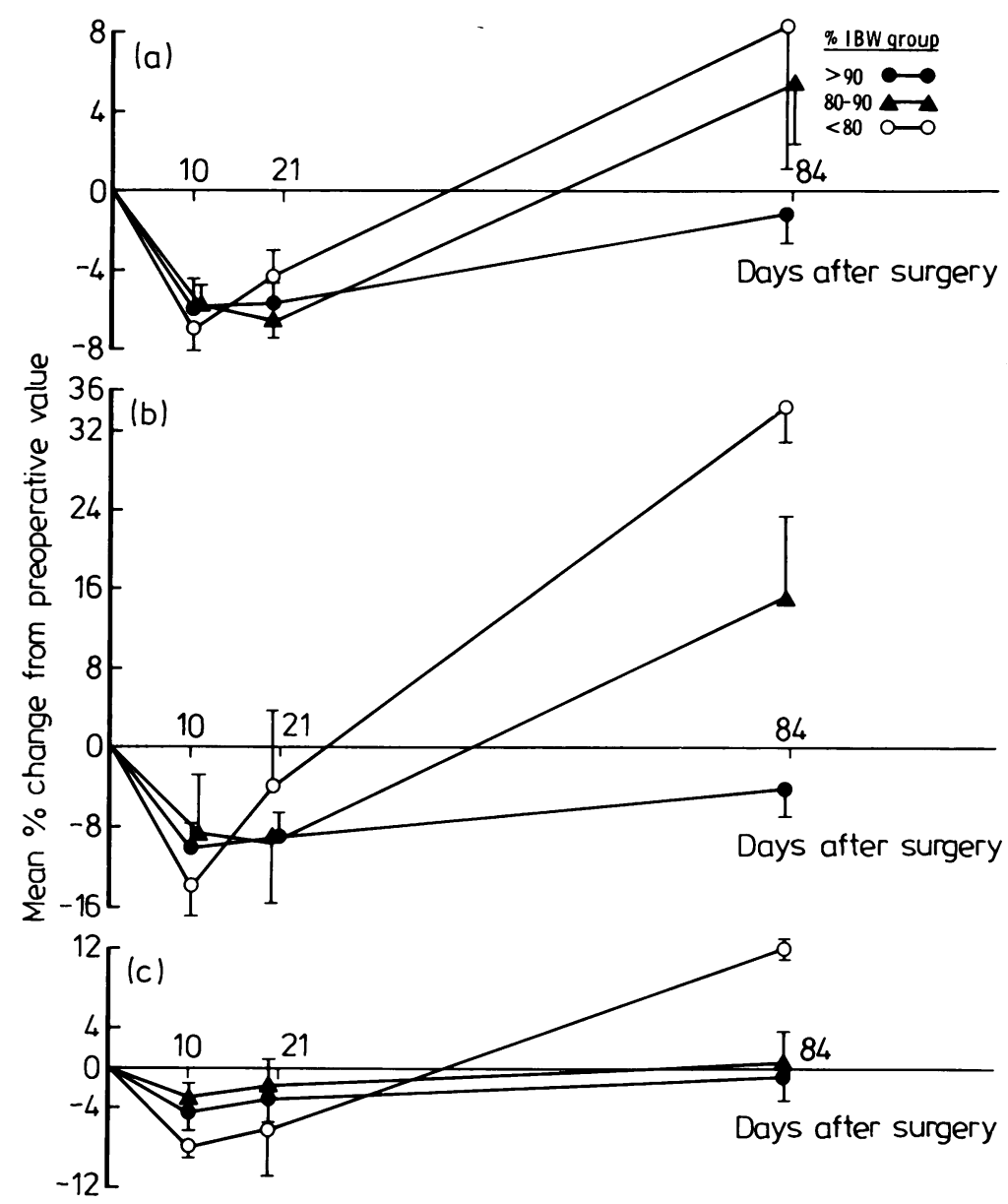


order as those described in studies after abdominal surgery. ${ }^{23} 24$

The severely malnourished patients preoperatively responded more rapidly in the postoperative period than the well nourished patients. This improvement resulted from an increase in fat and only a modest gain in muscle mass. This contrasts with the well nourished patients who were of similar nutritional status at 84 days postoperatively to their preoperative state.

The authors are grateful to the Small Grants Committee of the DHSS for financial support.

\section{References}

1 Bistrian BR, Blackburn GL, Hollwell H, Heddle RJ. Protein status of general surgical patients. JAMA 1974; 230: 858-60.

2 Wall AJ, Kirsner JB. in: Kirsner JB, Shorter RG, eds. Inflammatory bowel disease. Philadelphia: Lea and Febiger, 1975: 101-8.

3 Chandra RK. Nutrition as a critical determinant in susceptibility to infection. World Rev Nutr Diet 1976; 25: $166-88$.

4 Chandra RK. Influence of nutritional status on susceptibility to infection. Adv Nutr Res 1978; 2: 57-77.

5 Scrimshaw NS, Raylor CE, Gordon JE. Interactions of nutrition and infection. WHO Monogr Ser 1968; No 57.

6 Dubos RJ, Schaedler RW. Effect of dietary proteins and amino acids on the susceptibility of mice to bacterial infections. J Exp Med 1958; 108: 69-81.

7 Daly JM, Vars HM, Dubrick SJ. Effects of protein depletion on strength of colonic anastomosis. Surg Gynecol Obstet 1972; 134: 12-21.

8 Williams RHP, Heatley RV, Lewis MH, Hughes LE. A randomized controlled trial of pre-operative intravenous nutrition in patients with stomach cancer. Br J Surg 1976; 63: 667.

9 Mullen JL, Buzby GP, Matthews DC, Smale BF, Rosato EF. Reduction of operative morbidity and mortality by combined pre-operative and postoperative nutritional support. Ann Surg 1980; 192: 604-13.

10 Holter AR, Rosen HM, Fischer JE. The effects of hyperalimentation on major surgery in patients with malignant disease: a prospective study. Acta Chirug Scand (suppl) 1976; 466: 86-7.

11 Goodgame JT. A critical assessment of the indication for total parenteral nutrition. Surg Gynecol Obstet 1980; 151: 433-41.

12 Blackburn GL, Thornton PA. Nutritional assessment of the hospitalised patient. Med Clin North Am 1979; 63: 1103-15.

13 Hill GL, Pickford I, Young GA et al. Malnutrition in surgical patients. An unrecognised problem. Lancet 1977; 1: 689-92.

14 Society of Actuaries. Build and blood pressure study. Chicago: The Society, 1959; 1: 268.

15 Durnin JVGA, Womersley J. Body fat assessed from total body density and its estimation from skinfold thickness: measurements on 481 men and women aged from 16-72 years. Br J Nutr 1974; 32: 77-97.

16 Jelliffe EFP, Jelliffe DB. The arm circumference as a public health index of protein-calorie malnutrition of early childhood. J Trop Pediatr 1969; 15: 179-93.

17 Higgens CS, Keighley MRB, Allan RN. Impact of pre-operative weight loss on post-operative morbidity. J $R$ Soc Med 1981; 74: 571-3.

18 Fauci AS. Mechanisms of corticosteroid action on lymphocyte subpopulations. Immunology 1975; 28: 669-80.

19 Allsop JR, Lee ECG. Factors which influenced postoperative complications in patients with ulcerative colitis or Crohn's disease of the colon on corticosteroids. Gut 1978; 19: 729-34.

20 Hares MM, Greca F, Nevah E, Allan RN, Keighley MRB. Prolonged antibiotic cover is required to prevent sepsis after operations for inflammatory bowel disease. [Abstract] Gut 1981; 22: A437.

21 Young GA, Chem C, Hill GL. Assessment of protein calorie malnutrition in surgical patients from plasma proteins and anthropometric measurements. Am J Clin Nutr 1978; 31: 429-35.

22 Blackburn GL, Bistrian BR, Maini BS, Schlamm HT, Smith MF. Nutritional and metabolic assessment of the hospitalised patient. J Ent Parent Nutr 1977; 1: 11-22.

23 Hill GL, McCarthy ID, Collings JP, Smith AH. A new method for the rapid measurement of body composition in critically ill surgical patients. Br J Surg 1978; 65: $732-5$

24 Elbute EA. The effects of intravenous protein-calorie supplementation on the tissue composition of postoperative body weight loss. Postgrad Med J 1974; 50: 454-61. 